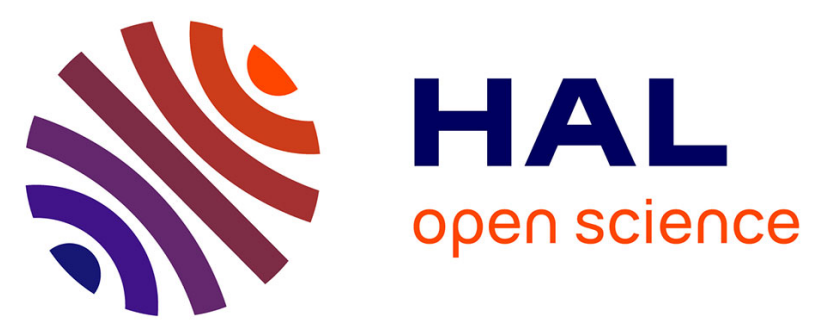

\title{
Micropollutants in urban stormwater: occurrence, concentrations, and atmospheric contributions for a wide range of contaminants in three French catchments
}

Johnny Gasperi, C. Sebastian, Véronique Ruban, M. Delamain, S. Percot, Laure Wiest, C. Mirande, E. Caupos, D. Demare, M Diallo Kessoo Kessoo, et al.

\section{To cite this version:}

Johnny Gasperi, C. Sebastian, Véronique Ruban, M. Delamain, S. Percot, et al.. Micropollutants in urban stormwater: occurrence, concentrations, and atmospheric contributions for a wide range of contaminants in three French catchments. Environmental Science and Pollution Research, 2014, 21 (8), pp.5267-5281. 10.1007/s11356-013-2396-0 . hal-00923251

\section{HAL Id: hal-00923251 \\ https://hal-enpc.archives-ouvertes.fr/hal-00923251}

Submitted on 23 May 2018

HAL is a multi-disciplinary open access archive for the deposit and dissemination of scientific research documents, whether they are published or not. The documents may come from teaching and research institutions in France or abroad, or from public or private research centers.
L'archive ouverte pluridisciplinaire HAL, est destinée au dépôt et à la diffusion de documents scientifiques de niveau recherche, publiés ou non, émanant des établissements d'enseignement et de recherche français ou étrangers, des laboratoires publics ou privés. 


\section{Micropollutants in urban stormwater: occurrence, concentrations and atmospheric contributions for a wide range of contaminants in three French catchments}

Gasperi J. ${ }^{1,}$ Sebastian C. ${ }^{2}$, Ruban V. ${ }^{3 * *}$, Delamain M. ${ }^{3}$, Percot S. ${ }^{3}$, Wiest L. ${ }^{4}$, Mirande C. ${ }^{1}$, Caupos E. ${ }^{1}$, Demare D. ${ }^{3}$, Diallo Kessoo M. ${ }^{5}$, Saad M. ${ }^{1}$, Schwartz JJ. ${ }^{5}$, Dubois P. ${ }^{1}$, Fratta C. ${ }^{4}$, Wolff H. ${ }^{5}$, Moilleron R. ${ }^{1}$, Chebbo G. ${ }^{1}$, Cren C. ${ }^{4}$, Millet M. ${ }^{5}$, Barraud S. ${ }^{2}$, Gromaire MC. ${ }^{1, * * *}$

1) Université Paris-Est, LEESU, UMR-MA 102-AgroParisTech, 6-8 avenue Blaise Pascal Cité Descartes, 77455 Champs-sur-Marne, France

2) Université de Lyon, INSA Lyon, Université Lyon 1, LGCIE, 34 avenue des Arts, 69621 Villeurbanne cedex, France

3) Institut Français des Sciences et Technologies des Transports, de l'Aménagement et des Réseaux, Route de Bouaye, BP 412944341 Bouguenais cedex, France

4) Université de Lyon, Institut des Sciences Analytiques - UMR 5280, CNRS, Université Lyon1, ENS-Lyon, Equipe TRACES, 5 rue de la Doua, 69100 Villeurbanne, France

5) Institut de Chimie et Procédés pour l'Energie, l'Environnement et la Santé, UMR 7515, 26 rue Becquerel, 67087 Strasbourg Cedex 2, France

Corresponding $\quad$ authors: $\quad$ *gasperi@u-pec.fr, $\quad+33(0) \quad 1.45 .17 .16 .21, \quad+33(0) \quad$ 1.45.17.16.27, **veronique.ruban@ifsttar.fr, +33(0) 2.40.84.58.65, +33(0) 2.40.84.59.98, ***gromaire@ leesu.enpc.fr, +33(0) 1.64.15.37.60, +33(0) 1.64.15.37.64 


\section{Abstract}

This study aimed at: i) providing information on the occurrence and concentration ranges in urban stormwater for a wide array of pollutants $(n=77)$; ii) assessing whether despite the differences between various catchments (land use, climatic conditions, etc.), the trends in terms of contamination level are similar; and iii) analyzing the contribution of total atmospheric fallout (TAF) with respect to sources endogenous to this contamination. The studied contaminants include conventional stormwater contaminants (polycyclic aromatic hydrocarbons - PAHs, $\mathrm{Zn}, \mathrm{Cu}, \mathrm{Pb}$, etc.), in addition to poorly or undocumented pollutants such as nonylphenol and octylphenol ethoxylates (NPnEO and OPnEO), bisphenol A (BPA), polybrominated diphenyl ethers (PBDEs), a wide variety of pesticides and various metals of relevance (As, Ti, Sr, V). Sampling and analysis were performed using homogeneous methods on three urban catchments with different land use patterns located in three distinct French towns. For many of these pollutants, the results do not allow highlighting a significant difference in stormwater quality at the scale of the three urban catchments considered. Significant differences were however observed for several metals (As, $\mathrm{Cr}, \mathrm{Cu}, \mathrm{Ni}, \mathrm{Sr}$ and $\mathrm{Zn}$ ), PAHs and PBDEs, though this assessment would need to be confirmed by further experiments. The pollutant distributions between dissolved and particulate phases were found to be similar across the three experimental sites, thus suggesting no site dependence. Lastly, the contributions of TAF to stormwater contamination for micropollutants were quite low. This finding held true not only for PAHs, as previously demonstrated in the literature, but also for a broader range of molecules such as BPA, NPnEO, OPnEO and PBDEs, whose high local production is correlated with the leaching of urban surfaces, buildings and vehicles.

\section{Keywords}

Atmospheric fallout; stormwater; urban hydrology; database; PAHs; metals; PBDEs; pesticides; bisphenol A; alkylphenols. 


\section{Introduction}

Since the 1980 's, many studies have demonstrated that urban stormwater contributes to the deteriorating quality of receiving waters (Brombach et al. 2005, Burton \& Pitt 2002, Clark et al. 2007). Initial investigations focused on carbonaceous and nutrient pollution, as well as on conventional pollutants such as heavy metals and polycyclic aromatic hydrocarbons (PAHs) (Brown \& Peake 2006). For the abovementioned contaminants, national and international databases were thus created, e.g. NURP (Smullen et al. 1999), NSQD (Pitt \& Maestre 2005), QASTOR (Saget 1994), and ATV databases (Fuchs et al. 2004). More recently however, runoff contamination by a wide array of organic contaminants has been highlighted. As reported in a recent review, a large number of compounds (over 650 identified) are currently present at trace concentrations in stormwater (Barbosa et al. 2012). Among these pollutants, studies have reported numerous pesticides (Muller et al. 2002), endocrine disruptors such as phthalates, alkylphenols and bisphenol A (Björklund et al. 2009) and priority pollutants listed in the European Water Framework Directive (Eriksson et al. 2007, Lamprea \& Ruban 2011a, Lamprea \& Ruban 2011b, Zgheib et al. 2012). In order to devise strategies that mitigate the stormwater contaminant impact at various decision-making levels (national, regional, local), in-depth knowledge of the occurrence of these compounds, their sources, concentrations and path in stormwater is definitely required since currently available data is limited. Moreover, a better understanding of pollution production and transfer from the atmosphere to the catchment outlet is needed. In the past, a relationship between pollutant loads, basin imperviousness, land use type (Burton \& Pitt 2002) and drainage infrastructure category (Brombach et al. 2005) had been investigated for common pollutants, though no clear insights are available today for the new contaminants being present in runoff. For some elements, Smullen et al. (1999) explained that the variations between NURP results and those derived from pooling the three national databases (NURP, USGS and NPDES) are significant and 
moreover that future work may provide a basis for differentiating Event Mean Concentrations (EMC) among urban land uses, geographic regions and seasons. Around the same time, Rossi (1998) showed that the variability for the same type of land use was so high, no clear conclusion could be drawn on these aspects. Nevertheless, this kind of information remains unavailable for a large range of pollutants; concentrations, fluxes and, to a broader extent, heterogeneity/homogeneity from one site to another was still not examined.

In France, beginning in 2010, various studies on pollutants in stormwater have been carried out on the country's three major field observatories, i.e. OTHU in Lyon (Field Observatory for Urban Water Management), OPUR in Paris (Observatory of Urban Pollutants) and ONEVU in Nantes (Nantes Observatory of the Urban Environment). On each observatory, special attention was paid to priority pollutants and certain metals such as $\mathrm{Zn}, \mathrm{Cu}, \mathrm{Pb}$ and $\mathrm{Cd}$ (Becouze-Lareure 2010, Bressy et al. 2011, Bressy et al. 2012, Gasperi et al. 2012, Lamprea \& Ruban 2011b, Zgheib et al. 2012). Due to differences in experimental methodologies (e.g. the choice of targeted pollutants, sampling procedures and analytical methods), the comparison among the various catchments failed to highlight differences from one site to another as regards stormwater quality. In this context and in order to address this issue, the INOGEV project (2010-2013, Innovations for a sustainable management of urban water Knowledge and control of the contamination of urban stormwater) was launched by the three observatories under the aegis of the French Observatory Network on Urban Hydrology (URBIS). This project is aimed at improving knowledge and procedures for assessing stormwater pollution contents as part of a multidisciplinary approach. By harmonizing scientific approaches and monitoring methodologies (pollutants, sampling, analytical methods and results interpretation) at the scale of three urban catchments, a new extended French dataset has been built. Its objectives are threefold: i) encompass a wide array of pollutants $(n=77)$, with knowledge of their occurrence rates and concentration ranges in stormwater; ii) 
assess the stormwater contamination in three catchments and determine whether parameters like land use or other local activities on catchments might explain differences; and iii) analyze the relative contributions of both atmospheric fallout and endogenous sources to this contamination. The present paper seeks to deliver initial conclusions based on this dataset.

\section{Materials and methodology}

\section{Site description and sampling procedure}

Three urban catchments, one on each observatory, were considered in this study, i.e. Sucy in Paris, Pin Sec in Nantes and Chassieu near Lyon (Figure 1). These catchments are all drained by conventional separate storm sewers (Table 1).

Figure 1: Locations of the three urban catchments considered for this study

Their areas range from 30 to 228 ha and their impervious surface coefficients (ISC) vary between $27 \%$ (Sucy) and $75 \%$ (Chassieu). Chassieu is an industrial area, whereas the other two catchments are mainly residential. Sucy is a residential district with mostly small singlefamily dwellings and limited commercial and professional activity (small retail spaces and services). The Pin Sec catchment is residential with mainly multi-family buildings and some single-family homes. On the whole, the majority of these buildings and houses were not built recently, dating back to the 1970's or 1980's. Heavy traffic loads are reported in Sucy, i.e. 60,000 vehicles.km. $\mathrm{d}^{-1}$, compared to loads in Chassieu $\left(36,000\right.$ vehicles.km. $\left.\mathrm{d}^{-1}\right)$ or Pin Sec

$\left(10,000\right.$ vehicles. $\left.\mathrm{km} \cdot \mathrm{d}^{-1}\right)$. Given the impervious surfaces of each catchment, the normalized traffic density is equal to 270,670 and 1,250 vehicles.km.d ${ }^{-1} \cdot$ ha $_{\text {imp }}{ }^{-1}$ in Chassieu, Pin Sec and Sucy, respectively.

Table 1: Urban catchment characteritics and description On each site, total atmospheric fallout (TAF) and stormwater at the catchment outlet were simultaneously collected. Depending on the site, between seven and 24 events were sampled (Table 2). Sampling was conducted over a 23-month period (from July 2011 to May 2013). 
Due to the large volumes required for these analyses (more than 20 liters for all pollutants in order to obtain suitable TSS masses for the particulate phase), it was not possible to analyze all contaminants during each single rain event. Two sampling configurations were thus deployed on each site: one for APnEO, PBDE and pesticide monitoring, and another configuration for PAH, glyphosate, AMPA and metal monitoring. Hence, between two and 14 events were sampled for a given family of compounds on a given catchment (Table 1). The number of rain events considered for each family and each catchment is listed in the individual results tables.

The main characteristics of these events, including precipitation depth $(\mathrm{H}$, in $\mathrm{mm})$, mean intensity over the rain event and maximum 5-min intensity ( $I_{\text {mean }}$ and $I_{\max }$, in $\mathrm{mm} \cdot \mathrm{h}^{-1}$ ) and preceding dry weather period (PDWP, in days), are shown in Table 2. On the whole, these rain events feature relatively low rainfall intensities, with no extreme rainfall amounts collected. Precipitation depth (from 1.2 to $50 \mathrm{~mm}$ ) and duration (00:35 to 60:35) both cover wide ranges.

Table 2: Rain event characteristics on the three study sites (min-max and median values) To avoid contamination or sorption, TAF was collected in a $1-\mathrm{m}^{2}$ stainless steel collector for organic pollutants and two $0.5-\mathrm{m}^{2}$ plastic collectors for metals and glyphosate. TAF values were measured for the period spanning the studied rain event and the preceding dry weather period. Atmospheric collectors were set up on rooftops at two sites and/or away from potential local sources, such as heavy road traffic, on all three catchments.

At the catchment outlet, stormwater was sampled using automatic samplers equipped with Teflon ${ }^{\circledR}$ pipes and plastic or glass bottles; samples were then controlled through a flow-meter in order to derive flow proportional event mean concentrations (EMC). Glass bottles were used for most organic pollutants, while plastic bottles were introduced for metals and three pesticides (glyphosate, glufosinate and its metabolite amino methyl phosphonic acid - AMPA) 
to avoid any potential sorption. For TAF and stormwater, the sampling equipment and procedure (cleaning steps, type of bottle, etc.) were consistent from one observatory to the next; moreover, the field blank procedure was harmonized.

\section{Conventional water quality parameters and pollutants analyzed}

Conventional water quality parameters, such as total suspended solids (TSS) and total dissolved and particulate organic carbon (TOC, DOC and POC), were analyzed for each rain event collected in terms of TAF and stormwater.

A total of 77 pollutants were monitored, including 14 metals, 30 pesticides, 16 polycyclic aromatic hydrocarbons (PAHs), nine polybrominated diphenyl ethers (PBDEs), bisphenol A (BPA) and seven alkylphenols (APnEO, including nonylphenol and nonyphenol mono and diethoxylates - NP, NP1EO and NP2EO - octylphenol and octylyphenol mono and diethoxylates - OP, OP1EO and OP2EO and nonylphenol acetic acid - NP1EC). Table 3 provides the full list of targeted molecules, the analytical methods employed and the usual abbreviations.

All compounds were analyzed over both the dissolved and particulate phases in order to evaluate their potential for transfer and further treatment processes. For all organic compounds, the dissolved and particulate phases were analyzed separately and not deduced from the total and dissolved phases because separate extraction of the two phases was found to be essential for an accurate quantification of contaminant levels (Zgheib et al. 2011b).

As regards the analytical methods employed, metals were analyzed by Inductively Coupled Plasma - Mass Spectrometry (ICP-MS) for the most part or by ICP-AES for Zn, in accordance with French standards (NF X 31-147) on the total and dissolved fractions. All organic pollutants were analyzed by either gas or liquid chromatography with a fluorescence detector or with a simple, tandem or time-of-flight mass spectrometer for both the dissolved and particulate fractions. All pollutants were quantified using internal standards. Further analytical 
details are available elsewhere for APnEO and bisphenol A (Cladière et al. 2013), pesticides (Schummer et al. 2012) and PBDEs (Gilbert et al. 2012). To avoid analytical bias, all analyses for a given class of contaminant were conducted by the same reference laboratory, i.e. Nantes for metals, Paris for BPA, APnEOs and PBDEs, Strasbourg for pesticides and Lyon for PAHs.

Table 3: Pollutants analyzed and analytical methods

Field blank results indicate no particular contamination from sampling devices and/or sample pre-treatment procedure for most pollutants monitored $(n=77)$. A low contamination by nonylphenol could however be observed $\left(<5 \mathrm{ng} \cdot \mathrm{l}^{-1}\right)$, but this value was far less than levels found in TAF or stormwater.

\section{Result interpretation methodology}

The first part of the results and discussion section will be dedicated to conventional water quality parameters in stormwater. Concentrations will be compared first across study sites and then to data from the literature, i.e. NURP database for the U.S. (Smullen et al. 1999) and QASTOR database in France (Saget 1994). To compare sites, the statistical distribution of stormwater EMC data for each site will be assessed. According to Smullen et al. (1999), EMCs for parameters or substances are most often log-normally distributed. In this study, lognormal distributions have been tested at 5\% significance levels (Shapiro-Wilk test, $\alpha=0.05$ ). Hence, both the mean and standard deviation (SD) of EMCs (estimated distribution) have therefore been calculated first in log space and then transformed into arithmetic space (USEPA 1989). In the second part of the results and discussion section, the occurrence and concentration ranges for all pollutants will be examined. Based on a similar methodology, the statistical distributions of each pollutant EMC will be evaluated and the differences in pollutant EMCs across sites assessed using the Kruskal-Wallis test at 5\%. For pollutants showing site-to-site differences, individual site concentrations will be presented. When no 
difference has been identified, data from all three sites will be pooled and global statistical parameters provided. The last parts will present the distribution of pollutants between the dissolved and particulate phases, as well as the contributions of total atmospheric fallout to stormwater contamination.

\section{Results and discussion}

\section{Conventional water quality parameters}

Conventional water quality parameters (TSS in $\mathrm{mg} . \mathrm{l}^{-1}$, DOC and POC in $\mathrm{mgC} . \mathrm{l}^{-1}$ ) are provided in Figure 2. On each site, EMCs for TSS, DOC and POC are log-normally distributed (Shapiro-Wilk test, $\alpha=0.05, \mathrm{~W}=0.93$ for Sucy and Pin Sec, $\mathrm{W}=0.79$ for Chassieu), and no significant differences appear across the three catchments (Kruskal-Wallis test, $\alpha=0.05$, $\mathrm{p}$-value $=0.478,0.167$ and 0.102 for TSS, DOC and POC). The measured TSS concentrations are in good agreement with those reported on the same sites in previous studies (Lamprea \& Ruban 2011b, Zgheib et al. 2011b). On the Chassieu catchment, based on on-line turbidity measurements from 2004 to 2011, the average TSS concentration during storm events was estimated at around $75 \mathrm{mg} \cdot \mathrm{l}^{-1}$ (Metadier \& Bertrand-Krajewski 2012). The concentrations found on these sites (mean values of 148, 129 and $100 \mathrm{mg} . \mathrm{l}^{-1}$ ) are much lower however than those previously reported in France by Saget (1994): a TSS of between 170 and $550 \mathrm{mg} \cdot \mathrm{l}^{-1}$ (with a median of roughly $420 \mathrm{mg} \cdot \mathrm{l}^{-1}$ ) on Paris catchments (QASTOR database). High concentrations of TSS found by Saget (1994) might reflect poor quality local sewer connections leading to the discharge of wastewater into the separate sewer. Since 1994, considerable effort has been devoted to improving these poor connections.

Figure 2: Concentrations (mean $\pm \mathrm{SD}$, in $\mathrm{mg}^{-1} \mathrm{l}^{-1}$ ) of conventional water quality parameters for stormwater for Sucy $(n=24)$, Pin Sec $(n=18)$ and Chassieu $(n=7)$

At the European scale, EMCs have been determined to lie within the same range as that reported by Fuchs et al. (2004) in Germany, i.e. with a mean TSS concentration of $150 \mathrm{mg} . \mathrm{l}^{-1}$ 
(265 sites). Similarly, EMCs display similar statistical parameters to those reported in the NURP database (Smullen et al. 1999), i.e. a mean and median TSS concentration of approx. 174 and $113 \mathrm{mg} . \mathrm{l}^{-1}$, respectively.

\section{Micropollutants}

\section{Occurrence of micropollutants on each catchment}

The occurrences (in \%) for each pollutant monitored, as well as the number of rain events considered, are reported in Table 4 for TAF and stormwater. The detection and quantification limits are provided in Supplementary Tables 1 and 2.

Table 4: Occurrence (\%) of pollutants in TAF and stormwater

Out of 77 pollutants monitored, between 42 and 48 substances (including metals, PAHs, PBDEs, APnEOs and bisphenol A (BPA)) were systematically detected, while 20 to 25 substances exhibited occurrence rates of less than $25 \%$. Overall, the occurrence profiles were quite homogenous across the 3 sites, except for some pesticides or low-level compounds. Out of 14 metals monitored, almost all were systematically detected in TAF and stormwater at each catchment outlet, except for Co, Mo and Pt. As regards their occurrence rates, no clear difference appeared from atmosphere to catchment outlet. It would therefore appear that the 14 trace metals analyzed within the scope of this survey were ubiquitous in both atmospheric deposition and stormwater, with no significant differences across the three sites. For Co, Mo

and Pt, the levels in TAF and runoff were below their detection limits $\left(0.6 \mu \mathrm{g} .1^{-1}\right.$ for Co and Mo, $0.01 \mu \mathrm{g} . \mathrm{l}^{-1}$ for Pt). For PAHs, six compounds (N, Acen, F, P, Fluo and Pyr) were systematically observed in TAF and stormwater regardless of the site considered. Regardless of the site under investigation, the $\mathrm{PAH}$ fingerprints were quite homogenous from one rain event to the next and from one site to the next. Yet, as illustrated in Figure 3, TAF and stormwater present different PAH fingerprints. PAH patterns for TAF are characterized by the predominance of low molecular weight PAHs (LMW, 2-4 aromatic rings) compared to heavy 
molecular weight PAHs (HMW, i.e. 5-6 aromatic rings) as attested by a mean LMW/HMW ratio of approximately 12. This difference traduces direct deposition on urban surfaces of HMW PAHs emitted by either combustion (vehicle exhaust) or petroleum sources (rubber tires, oil leakage, asphalt materials (Yunker et al. 1999)) whereas the LMW PAHs can be transported over large distance via the atmosphere. As, in urban context, the PAH distributions in stormwater reflect a mixture of pyrolytic and petrogenic contamination (Soclo et al. 2000).

Of the 30 pesticides evaluated, 19 compounds - broken down into five herbicides (metazachlor, terbutryn, pendimethalin, trichlopyr and acetochlor), five fungicides (folpel, epoxiconazole, fenpropidine, chlorothalonil and tebuconazole), six insecticides (chlorfenviphos, endosulfan, aldrin, dieldrin, isodrin and deltamethrine) and three algaecides/molluscicides (isothiazolinone, irgarol 1051 and metaldehyde) - were never detected in stormwater or with an occurrence rate of below $20 \%$, regardless of the catchment considered. The detection limits of most of these compounds lie in the range of 2-7 ng. $\mathrm{l}^{-1}$. Of these compounds, some (such as aldrin and dieldrin) are now banned: the non-detection may be explained by having been phased out from use in France. In spite of reports surrounding their leaching of additives from recent construction materials (Burkhardt et al. 2011), terbutryn, irgarol 1051 and isothiazolinone were also not detected. As a matter of fact, seven herbicides (glyphosate, glufosinate and its degradation product AMPA, diuron, isoproturon, mecoprop and 2,4-MCPA) and one fungicide (carbendazim) were frequently observed in stormwater, and this finding remained independent of the site tested. In general, these compounds exhibited occurrences varying between $20 \%$ and $100 \%$ in runoff, e.g. mecoprop 0-50\%; isoproturon 29-100\%; 2,4-MCPA 29-75\%. More details on their occurrence rates are provided in Table 5. A similar trend was observed in TAF. As regards occurrence, slightly higher rates of these herbicides were noted at the scale of larger basins (i.e. Sucy and 
Chassieu), comparatively to Pin Sec. Given that the pesticide presence in stormwater is highly dependent on site and peripheral activities, this could suggest that the pesticide use could tend to be more limited and specific on smaller catchments. This finding may also reflect the results of the new policy being implemented in the Nantes Metropolitan Area targeting a drastic reduction in pesticide use on public spaces. The Pin Sec catchment is in fact affected by the same kind of this policy. Chassieu, which have, at the present, the less drastic policy in terms of pesticide reduction shows the higher level of occurrence in TAF and Stormwater for most of the pesticides analyzed.

Diuron and glyphosate are used as total herbicides and their presence in stormwater may be explained by its application on different types of urban surfaces (Blanchoud et al. 2004, Botta et al. 2009, Kolpin et al. 2006). At the scale of the Paris conurbation and prior to 2008, diuron accounted for about $31 \%$ of urban pesticide use (Blanchoud et al. 2007). At present, in spite of its recent ban in France (December, 2008) from phytopharmaceutical products, diuron is being increasingly added to building facade paints and renders in order to provide antialgal and antifungal protection (Burkhardt 2006). Glyphosate is widely used by municipalities and home gardeners; this tendency has been verified in a recent survey conducted at Pin Sec, which showed that in spite of information delivered by local authorities, herbicides (and especially glyphosate) are still being used. Based on experimental batch tests conducted on surfaces of varying imperviousness, Blanchoud et al. (2007) estimated the transfer coefficients (i.e. the ratio between quantity of pollutants at the catchment outlet and quantity of pollutants input on this catchment) to equal roughly $60 \%$ for diuron and $25 \%$ for glyphosate. Carbendazim were also reported to be leached from new antifouling paints and renders (Burkhardt et al. 2007). Mecoprop and 2,4-MCPA are mainly applied for yards, parks and railway maintenance.

Out of the nine PBDEs monitored, high occurrence rates were observed for five compounds 
(BDE-28, 47, 99, 100 and 209) while other congeners (BDE-153, 154, 183 and 205) were less frequently detected. This finding is in good agreement with typical PBDE fingerprints reported in literature and moreover corresponds to the PBDE commercial mixtures such as penta-, octa- and deca-mix (Hites 2004). Due to growing environmental and human health concerns, penta- and octa-BDE and, more recently, deca-BDE have been banned in Europe though they are still being detected. The presence of PBDEs in TAF has been widely reported (Muresan et al. 2010, Tlili et al. 2012). Furthermore, as underscored by Muresan et al. (2010), BDE-47, BDE-99 and BDE-209 contribute from $50 \%$ to $80 \%$ of the total atmospheric flux. To date however, no study has focused on their occurrence in runoff. Their presence in runoff was nevertheless anticipated since PBDEs are found in TAF and have commonly been added to building materials, automotive parts, plastics and electronic equipment (Hites 2004).

Lastly, BPA and APnEO (NP, NP1EO, NP2EO, NP1EC, OP, OP1EO and OP2EO) were systematically observed in runoff and TAF. Nonylphenol ethoxylate (NPnEO, 80\%) and octylphenol ethoxylate (OPnEO, 20\%) are widely used in industrial and domestic applications, such as lubrication, oil additives, detergents and antistatic agents (Ying et al. 2002). The presence of NP and OP in stormwater had been expected since both compounds are used in paints, concrete, building materials, asphalt and certain vehicle parts (European Chemicals Bureau 2002). Nonylphenol acetic acid (NP1EC), which is a degradation product of NPnEO, is also frequently identified in both matrices. BPA is primarily used as a monomer in the manufacturing of polycarbonate plastics, renowned for its high resistance to shocks and temperature (e.g. plastic windows, car bumpers), as well as in epoxy resins (Staples et al. 1998). BPA is also an admixture introduced during the production of PVC, varnishes and paints, and in the formulation of some car products (brake fluid, tires). Its presence in TAF (Cladière et al. 2013) and runoff (Kalmykova et al. 2013) has been recently reported.

\section{Concentration ranges of pollutants in stormwater}


The statistical parameters of EMC distributions are indicated in Table 5 for pollutants that display site-to-site differences and Table 6 for the other pollutants.

Table 5: Pollutant concentrations (mean $\pm \mathrm{SD}$ ) in stormwater displaying site-to-site

$$
\text { differences }
$$

Table 6: Pollutant concentrations (mean $\pm \mathrm{SD}, \mathrm{Q} 20$ and Q80) in stormwater displaying no site-to-site differences

\section{- Metals}

From an overall standpoint, metal EMC ranges varied by one or more orders of magnitude from one sample to another. These concentration values were in the same range as previous recordings at these sites (Becouze-Lareure 2010, Lamprea \& Ruban 2011b, Percot 2012) but in the lower part of the range compared to data reported in the literature (Rossi 1998, Sabin et al. 2005). It should be highlighted that the INOGEV project has contributed new information on the elements As, Co, Mo, Pt, Sr, Ti and V, which had seldom been reported in the literature previously. For Mo (1-12 $\mu \mathrm{g} . \mathrm{l}^{-1}$, Q20 and Q80), Co (1-3.5 $\left.\mu \mathrm{g} .1^{-1}\right), \mathrm{Pb}\left(7-35 \mu \mathrm{g} . \mathrm{l}^{-1}\right), \mathrm{V}$ (3-7 $\left.\mu \mathrm{g} . \mathrm{l}^{-1}\right)$, Ti $\left(10-37 \mu \mathrm{g} . \mathrm{l}^{-1}\right)$ and $\mathrm{Cd}\left(0.12-0.42 \mu \mathrm{g} . \mathrm{l}^{-1}\right)$, our results do not indicate any site-tosite differences at the scale of the three urban catchments studied. Statistical parameters of the EMC distribution are reported in Table 6. For $\mathrm{As}, \mathrm{Cu}, \mathrm{Cr}, \mathrm{Ni}, \mathrm{Zn}$ and $\mathrm{Sr}$, differences between sites appeared and concentrations on each site are given in Table 5. Higher $\mathrm{Cr}$ and $\mathrm{Ni}$ concentrations were found at Chassieu, most likely as a result of local industrial activities. The highest $\mathrm{Cu}, \mathrm{Zn}, \mathrm{Sr}$ and $\mathrm{Ti}$ concentrations were reported at Sucy. Interestingly, these metals are known to originate from vehicle brake linings and tires (Sternbeck et al. 2002, Thorpe \& Harrison 2008), thus suggesting that differences could be highly correlated with traffic density. Initial estimations actually revealed significantly different traffic densities on each site, i.e. approx. 1,250 vehicles.km.d $\mathrm{d}^{-1} \cdot \mathrm{ha}_{\mathrm{imp}}{ }^{-1}$ at Sucy vs. 270 and 670 vehicles.km.d ${ }^{1}$.haimp ${ }^{-1}$ at Chassieu and Pin Sec. The $\mathrm{Zn}$ contamination might also be attributed to leaching 
from roofs, gutters, street furniture, etc. The higher $\mathrm{Ni}$ and $\mathrm{Cr}$ concentrations measured at Chassieu could be explained by the presence of industries on this catchment but these concentrations did remain low.

\section{- $P A H s$}

The PAH results are discussed on the basis of total concentrations, i.e. $\sum 16$ US-EPA PAHs or $\sum_{13}$ PAHs (excluding N, Acen and Acyl). Whereas no significant difference was found for TAF across the 3 sites, statistical analyses revealed significant site-to-site differences for total PAH concentrations in stormwater ( $\sum_{13}$ PAHs, Kruskal-Wallis test, $\alpha=0.05, p$-value $=$ 0.031). Moreover, Chassieu (644 ng..$^{-1}$ for $\sum_{13}$ PAHs, Table 6) and Pin Sec (723 ng..$^{-1}$ ) presented lower concentrations than Sucy $\left(1,237 \mathrm{ng} \cdot \mathrm{l}^{-1}\right)$. The concentrations measured on Sucy lie within the same range as those reported by Zgheib et al. (2011a) on the Sucy site (880, 3,300 and 6,480 $\mathrm{ng}^{-1} \mathrm{l}^{-1}$ respectively for the minimum, average and maximum concentrations of $\sum{ }_{16}$ PAHs), which confirms a higher PAH contamination on this catchment than on the others. Another interesting point is that even though TSS concentrations vary within the same range on all 3 sites, the differences observed are primarily tied to the PAH contents of the particles collected. The median PAH content found in Sucy (approx. 19,000 ng. $\left.\mathrm{g}^{-1}\right)$ far surpasses that reported for Chassieu $\left(6,000 \mathrm{ng} \cdot \mathrm{g}^{-1}\right)$ or Pin Sec $\left(7,000 \mathrm{ng} \cdot \mathrm{g}^{-1}\right)$. On the whole, the stormwater concentrations are much higher than those observed in TAF, thus indicating a local production source. No correlation was found between PAHs, TSS and dissolved and particulate organic carbon levels (Spearman test, $\mathrm{R}^{\mathbf{2}}<0.3$ ). In addition and based on the limited number of rain events, no seasonal correlation was identified. As previously mentioned for vehicle-derived metals, the contamination in stormwater likely reflect a difference in road traffic density and type from one catchment to another. In accordance with the extensive literature, PAHs are indeed emitted by vehicle traffic via gas exhaust, tire wear and spilled oil (Yunker et al. 2002). The highest concentrations were 
consistently found for Sucy, which is subjected to much higher traffic density. The industrial catchment of Chassieu generated the lowest PAH concentrations, except for the extremely high concentrations of naphthalene measured on some samples. These low PAH concentrations were unexpected, due to the numerous industrial and logistics activities in Chassieu as well as the proximity to Lyon's dense highway corridor, yet they remain consistent with the low traffic density inside the catchment ( 270 vehicles.km. $\mathrm{d}^{-1} \cdot \mathrm{ha}_{\mathrm{imp}}{ }^{-1}$ ).

\section{- Pesticides}

Among the most widely detected pesticides, glyphosate (95-198 ng. $\mathrm{l}^{-1}, \mathrm{Q} 20$ and Q80), AMPA (16-469 ng. $\left.\mathrm{l}^{-1}\right)$, diuron (25-795 ng. $\left.\mathrm{l}^{-1}\right)$ and glufosinate (6-389 $\left.\mathrm{ng} . \mathrm{l}^{-1}\right)$ are all non-selective herbicides and were predominant in stormwater. Isoproturon (3-53 ng. ${ }^{-1}$ ) and carbendazim (7-195 ng. $\left.\mathrm{l}^{-1}\right)$ were detected at lower concentration levels, while the remaining pesticides (mecoprop, 2,4-D, 2,4-MCPA) did not generally exhibit concentrations reaching 5 ng. $\mathrm{l}^{-1}$. Given the limited number of rain events for these compounds (from four to eight events, depending on the site), the difference in herbicide concentrations between sites was not statistically tested and instead the data were pooled (Table 6). Given that some studies focused on pesticide in rainwater or the transfer of certain compounds in urban areas (Blanchoud et al. 2004, Huang et al. 2004, Quaghebeur et al. 2004), it can be stated that the presence of these herbicides and the significance of their concentrations in stormwater from urban areas are both poorly documented, with the exception of some data collected at the same sites (Becouze-Lareure 2010, Lamprea \& Ruban 2011a, Zgheib et al. 2012).

High glyphosate concentrations were measured on Pin Sec, where municipal use of this pesticide is limited. At the scale of our three study sites, it can reasonably be assumed that glyphosate is being used by private gardeners. Diuron and carbendazim were reported to be leached at high concentrations from new antifouling paints and renders (Burkhardt et al. 2007). This source would be consistent with the much lower concentrations measured on 
Chassieu (with industrial-type buildings), compared to Sucy and Pin Sec, though it remains limited to relatively new or recently renovated facades. Despite the ban, dated supplies of diuron-based pesticides might still be used by private gardeners or else have accumulated in the soils. High herbicide concentrations were occasionally observed (1,500-3,000 ng. $\left.1^{-1}\right)$ independent of the site or period under consideration. These high concentrations depend on various factors affecting the quantity of pesticides remobilized, such as the time interval between applications and rainfall, the level of imperviousness of the treated surface or the characteristics of the rain events (Huang et al. 2004).

\section{- PBDES}

Of the eight PBDEs detected in runoff, deca-BDE (BDE-209) displayed the highest concentrations, in ranging from 23 to $251 \mathrm{ng}^{\mathrm{l}^{-1}}$ (Q20 and Q80 on the full dataset) and with a median relative contribution to $\sum_{8}$ PBDEs of around $90 \%$. The other congeners varied overall within the 0.5-3.0 ng. $1^{-1}$ range. For tri- to hepta-BDEs, BDE-47 and BDE-99 were the most abundant congeners, with mean relative abundances of $5 \%$ and $3 \%$, respectively. While the PBDE contamination of the atmospheric compartment is known (Muresan et al. 2010, ter Schure et al. 2004, Tlili et al. 2012), no experimental data on PBDE levels in stormwater were available. Although no geographical difference was noticed for TAF contamination, significant site-to-site differences were observed for stormwater contamination $\left(\sum 9 \mathrm{PBDE}\right.$, Kruskal-Wallis test, $\alpha=0.05, \mathrm{p}$-value $=0.017$, Table 5). This finding suggests that land use and/or building materials applicable to these catchments might affect runoff differently. Lower PBDE concentrations were actually found in Sucy, as compared to the other catchments. To date, any more comprehensive explanation has not been provided. For all sites under consideration, BDE-209 concentrations at the catchment outlet were significantly higher than those either measured in TAF during this study $\left(0.4-8.6\right.$ ng..$\left.^{-1}\right)$ or reported for Sweden in urban areas (2.5-14.4 ng. $\mathrm{l}^{-1}$ for $\sum_{8}$ PBDEs, ter Schure et al. 2004). 
For BPA and APnEO, no site differences were observed (Kruskal-Wallis test, $\alpha=0.05$, pvalue $=0.035$ for BPA and $\mathrm{p}$-value $=0.111$ for APnEOs). The statistical parameters associated with their distributions are listed in Table 6. The mean EMCs of BPA and NP were estimated at 552 and 359 ng. l $^{-1}$. For both compounds, these concentrations were much higher than those reported for rainwater in Paris (10-180 ng. $1^{-1}$ for BPA and < LOD-167 ng..$^{-1}$ for NP (Cladière et al. 2013)) and in the same overall range as results for runoff and landfill leachate in Sweden (< LOD-107 000 ng. l $^{-1}$ for BPA and < LOQ-7300 ng..$^{-1}$ for NP (Kalmykova et al. 2013)). On the French national scale, NP levels were also comparable to those reported by Bressy et al. (2012), i.e. 160-920 ng.1 ${ }^{-1}$ (d10-d90). Nonylphenol (NP) and nonylphenol ethoxylates (NP1EO and NP2EO) were predominant, in comparison with octylphenol (OP) and octylphenol ethoxylates (OP1EO and OP2EO). In our study, NP tends to exhibit higher concentrations than NP1EO and NP2EO; these findings contrast with the Swedish results. Regardless of the site and rain event considered, the alkylphenol distributions remained fairly homogenous, as characterized by the following order: NP $(42 \pm 25 \%)>\operatorname{NP} 1 \mathrm{EO}(25 \pm 11 \%) \approx$ NP1EC $(21 \pm 9 \%)>$ NP2EO $(12 \pm 4 \%)$. For the first time, the presence of NP1EC has been reported in runoff, with concentrations significantly greater than those measured in TAF $(<3$ ng. $\left.\mathrm{l}^{-1}\right)$. Unlike Bjorklund et al. (2009) and from a practitioner's point of view, a positive correlation of NP1EO and NP2EO (Spearman test, $\mathrm{p}$-value $=0.005$ and $0.008, \mathrm{R}^{2}=0.558$ and 0.583) with dissolved organic carbon (DOC) was found. As regards the Water Framework Directive, the Environmental Quality Standard defined for NP (300 ng..$^{-1}$ ) was frequently exceeded (11 times in 22 sampled events).

\section{Distribution of pollutants between dissolved and particulate phases}

The distributions of all pollutants between dissolved and particulate phases are shown in Table 7. For all pollutants examined, no significant differences across the three sites were 
remarked, thus suggesting that this distribution is not site-dependent but rather correlated with the physical and chemical properties of the compound under consideration. This assessment could prove useful in the choice of stormwater treatment device.

Table 7: Percentage of metals and organic pollutants in the particulate phase in stormwater Most metals were mainly bound to the particulate phase (> 50\%), except for Sr. This tendency was more highly pronounced for $\mathrm{Co}, \mathrm{Cr}, \mathrm{Pb}$ and $\mathrm{Ti}$, and to a lesser extent for $\mathrm{Cu}$. The remaining metals ( $\mathrm{As}, \mathrm{Cd}, \mathrm{Ni}, \mathrm{V}, \mathrm{Mo}$ and $\mathrm{Zn}$ ) yielded an intermediate behavior since the mean particulate phase ranged from $48 \pm 18 \%$ (As) to $63 \pm 40 \%$ (Mo). The distribution of metals between dissolved and particulate phases has been previously assessed for samples collected from street runoff (Gromaire-Mertz et al. 1999), in which similar trends were reported, i.e. metals were mainly particle-bound since averages of $97 \%, 83 \%, 67 \%$ and $52 \%$ of total $\mathrm{Pb}, \mathrm{Cd}, \mathrm{Cu}$, and $\mathrm{Zn}$, respectively, were associated with suspended solids.

The distribution of organic pollutants between dissolved and particulate phases is highly dependent on their chemical and physical properties. In accordance with typical stormwater findings, most organic pollutants studied herein are preferentially associated with particles. For instance, $50 \%$ to $80 \%$ of LMW PAHs were bound to the particulate phase and HMW PAHs displaying higher hydrophobicity were observed in the particulate phase at a rate of over $80 \%$. A similar trend was found for PBDEs, as would be expected from their $\log \mathrm{K}_{\mathrm{ow}}$, which ranged between 5.8 and 9.0. For these compounds, conventional management solutions based on settling treatment systems (Pitt et al. 1995) appear to be relevant and in good agreement with our results. In contrast and as previously observed for nonylphenol (Bressy et al. 2011), this study has demonstrated that the dissolved fraction is considerable for some contaminants such as pesticides, BPA and APnEO. BPA $\left(\log \mathrm{K}_{\mathrm{ow}}=2.2-3.2\right)$, OP1EO $\left(\log \mathrm{K}_{\mathrm{ow}}\right.$ $=4.1)$ and NP1EC (log $\mathrm{K}_{\mathrm{ow}}$ undetermined) were mainly observed in the dissolved fraction (Table 7). For APnEO exhibiting a $\log \mathrm{K}_{\mathrm{ow}}$ of between 4.0 and 5.7, the mean particulate 
proportion did not exceed $45 \%$. In spite of the relative high $\log \mathrm{K}_{\mathrm{ow}}$ value, this behavior might still be explained by APnEO molecular structural properties (amphiphilic compounds) or else by the non-equilibrium status within the separate sewer. Along the same lines, diuron (log $\left.\mathrm{K}_{\mathrm{ow}}=2.7\right)$, isoproturon $\left(\log \mathrm{K}_{\mathrm{ow}}=2.9\right)$, glyphosate $\left(\log \mathrm{K}_{\mathrm{ow}}=-4.0\right)$ and glufosinate $\left(\log \mathrm{K}_{\mathrm{ow}}\right.$ $=-5.3)$ are all preferentially associated with the dissolved fraction. Their distributions between dissolved and particulate phases are in good agreement with their extremely low log $\mathrm{K}_{\mathrm{ow}}$ values. The partitioning of AMPA $\left(\log \mathrm{K}_{\mathrm{ow}}=-0.82\right)$ was not calculated since this compound was detected in the particulate phase, a finding that may be primarily correlated with a high detection limit for this compound in the dissolved phase (i.e. 60 ng. $1^{-1}$ for AMPA). Despite the fact that $\log \mathrm{K}_{\mathrm{ow}}$ does not accurately describe the behavior of all pesticides, this coefficient can still be used as an indicator to predict the pollutant distribution between dissolved and particulate fractions. Other parameters however might also affect the partitioning, e.g. molecular structures and charges.

\section{Contribution of atmospheric deposition to stormwater pollution}

For each pollutant, the contributions of total atmospheric fallout to stormwater pollution have been calculated. At the scale of the rain event, the ratio between TAF and stormwater concentrations was evaluated; the mean \pm SD values of this ratio are given in Table 8 .

Table 9: Contributions (in \%) of TAF to stormwater pollution

Except for several individual substances, the contributions of TAF were on the whole rather weak, and median values generally did not exceed $30 \%$. For metals and as a result of low concentrations found on all three sites for TAF $\left(<1 \mu \mathrm{g} .1^{-1}\right.$ for As, Cr, Ni and V; 2-4 $\mu \mathrm{g} . \mathrm{l}^{-1}$ for Sr; 3-12 $\mu \mathrm{g} . \mathrm{l}^{-1}$ for $\mathrm{Cu}$; and $15-50 \mu \mathrm{g} . \mathrm{l}^{-1}$ for $\mathrm{Zn}$ ), total atmospheric fallout accounted for less than $20 \%$ of the stormwater pollution for 6 metals ( $\mathrm{As}, \mathrm{Pb}, \mathrm{Sr}, \mathrm{Ti}, \mathrm{V}$ and $\mathrm{Cu}$ ) though in some cases $(\mathrm{Cd}, \mathrm{Cr}, \mathrm{Ni})$ did exceed $30 \%$. For As, Sr, and V, this contribution did not exceed $10 \%$. Overall, the ratios between TAF and stormwater were quite similar at the scale of these three 
sites, except for $\mathrm{Cr}, \mathrm{Sr}$ and $\mathrm{Zn}$. Differences were readily observed for $\mathrm{Cr}$ (55\% at Pin Sec vs. $8 \%$ and $10 \%$ at Chassieu and Sucy), Sr (14\% at Pin Sec vs. 5\% and 3\% at Chassieu and Sucy) and Zn (86\% at Pin Sec vs. 9\% and 15\% at Chassieu and Sucy). A very high atmospheric Zn contribution was observed on Pin Sec $(86 \% \pm 127 \%)$, which was mainly due to the first three campaigns (December 2011 through March 2012), during which unusually high atmospheric concentrations were measured $\left(122-537 \mu \mathrm{g} . \mathrm{l}^{-1}\right)$. These increased concentrations may be attributed to specific works involving zinc sheets in the vicinity of the sampling device; however, this hypothesis could not be verified. Long-range transportation is rejected as an explanation since TSS did not increase during this period.

For PAHs, PBDEs, APnEO and BPA, atmospheric contributions remained low, thus confirming a strong local production for all compounds. Except for PAHs and NP, this production has not been highlighted in the literature for such a broad panel of substances. As regards PAHs, and according to the literature, the street system appears to be the primary source of PAHs in urban runoff (Motelay-Massei et al. 2006). For other families, such as APnEOs and PBDEs, local production from road, urban surfaces and vehicle leaching would be expected since these compounds are used in building materials and automobile parts. As mentioned for PAHs, the sources of these compounds now need to be investigated more thoroughly. Consequently, samples from street runoff will soon be analyzed as a follow-up to this work.

\section{Conclusion}

This paper has been developed as part of the INOGEV project being carried out by the three French Observatories in Urban Hydrology (OPUR, OTHU and ONEVU) focusing on stormwater quality and intended to deliver the initial conclusions drawn from a new more extensive French dataset.

This study has provided, for a wide array of pollutants and three distinct catchments featuring 
distinct land use patterns and contexts, a knowledge and comparison of their occurrence rates and concentration ranges in stormwater with the same experimental procedures for each site. Relevant data have been derived for newly targeted metals (As, Ti, Sr, V) and heretofore poorly documented organic pollutants, such as nonylphenol and octylphenol ethoxylates, PBDEs, certain pesticides and BPA. Such a database could be used to develop a relevant decision-making aid for urban stormwater practitioners and watershed managers in evaluating the stormwater contribution to the pollution of receiving waters.

For many pollutants, the results obtained during this monitoring program do not highlight any significant difference in stormwater quality across the three urban catchments studied, with variability from one site to another being of the same order of magnitude or less than variability from one event to another. This study has not only confirmed the initial conclusions drawn at the scale of three Paris catchments (Zgheib et al. 2011a), but has reinforced them since the urban catchments considered in the INOGEV project are more highly contrasted than those initially examined. This study however also underscores significant site-to-site differences for several metals ( $\mathrm{As}, \mathrm{Cr}, \mathrm{Cu}, \mathrm{Ni}, \mathrm{Sr}$ and $\mathrm{Zn}$ ), as well as for PAHs and PBDEs.

Like for stormwater quality, this study reveals no significant differences in the distribution between dissolved and particulate phases across all sites, which suggests that this distribution is not site-dependent but instead correlated with the physical and chemical properties of the compound being examined. In accordance with typical stormwater observations, most metals were primarily bound to the particulate phase: i) > 50\% for $\mathrm{As}, \mathrm{Cd}, \mathrm{Mo}, \mathrm{Ni}, \mathrm{V}, \mathrm{Cu}$ and $\mathrm{Zn}$; and ii) $>80 \%$ for $\mathrm{Co}, \mathrm{Cr}, \mathrm{Pb}$ and $\mathrm{Ti}$. For organic pollutants, their distributions between dissolved and particulate phases depend heavily on their chemical and physical properties; moreover, it appears that the octanol-water coefficient $\left(\log \mathrm{K}_{\mathrm{ow}}\right)$ of these substances may be used to roughly predict their behavior. Log $\mathrm{K}_{\mathrm{ow}}$ actually serves as an empirical predictive 
approach for easily determining the distributions between dissolved and particulate phases of pollutants, yet the relation between $\mathrm{K}_{\mathrm{ow}}$ (or another coefficient, like $\mathrm{K}_{\mathrm{oc}}$ or $\mathrm{Kd}$ ) and substance distribution in stormwater still requires further investigation.

In conclusion, this study has highlighted that the contributions of TAF were either rather low or very low for quality parameters and micropollutants, with median values not exceeding $30 \%$ except for certain individual substances. This extremely relevant finding underscores local production not only for PAHs, as previously demonstrated in the literature, but also for a broader range of substances such as BPA, APnEOs and PBDEs. This local production is correlated with leaching from urban surfaces, buildings and vehicles, although their actual sources must now be more thoroughly investigated.

In pursuing this work and in addition to the initial conclusions delivered, a deeper analysis between groups of pollutants (correlation trends) will be carried out in order to select representative substances to be studied. Atmospheric and stormwater fluxes at various temporal scales will also soon be evaluated and compared in order to assess the relative contribution of atmospheric inputs. Stormwater quality relative to rain event characteristics will also be studied. Subsequent investigations will rely on developing a methodology and tools for estimating annual stormwater pollutant fluxes at the scale of urban catchments based on on-line turbidity measurements.

\section{Acknowledgments}

This study has been conducted within the framework of the INOGEV research program, which was funded by the French National Research Agency (under its "Villes Durables" program). The authors would like to thank all project partners, namely the Greater Lyon and RM\&C Water Agency, the Nantes Metropolitan Council, the Val-de-Marne Council for their technical and financial support, as well as the three Observatories OPUR, OTHU and ONEVU plus the SOERE URBIS for their scientific contributions. 
5. References 
Barbosa AE, Fernandes JN, David LM (2012): Key issues for sustainable urban stormwater management. Water Research 46, 6787-6798.

Becouze-Lareure C 2010: Caracterisation and assessement of priority pollutant flux in stormwater at the scale of two urban catchments, PhD Thesis INSA de Lyon, 308 (in French) pp.

Björklund K, Cousins AP, Strömvall A-M, Malmqvist P-A (2009): Phthalates and nonylphenols in urban runoff: Occurrence, distribution and area emission factors. Science of the Total Environment 407, 4665-4672.

Blanchoud H, Farrugia F, Mouchel JM (2004): Pesticide uses and transfers in urbanised catchments. Chemosphere 55, 905-913.

Blanchoud H, Moreau-Guigon E, Farrugia F, Chevreuil M, Mouchel JM (2007): Contribution by urban and agricultural pesticide uses to water contamination at the scale of the Marne watershed. Science of the Total Environment 375, 168-179.

Botta F, Lavison G, Couturier G, Alliot F, Moreau-Guigon E, Fauchon N, Guery B, Chevreuil M, Blanchoud H (2009): Transfer of glyphosate and its degradate AMPA to surface waters through urban sewerage systems. Chemosphere 77, 133-139.

Bressy A, Gromaire MC, Lorgeoux C, Chebbo G (2011): Alkylphenols in atmospheric depositions and urban runoff. Water Science and Technology 63, 671-679.

Bressy A, Gromaire MC, Lorgeoux C, Saad M, Leroy F, Chebbo G (2012): Towards the determination of an optimal scale for stormwater quality management: Micropollutants in a small residential catchment. Water Research 46, 6799-6810.

Brombach H, Weiss G, Fuchs S (2005): A new database on urban runoff pollution: comparison of separate and combined sewer systems. Water Science and Technology 51, 119-128.

Brown JN, Peake BM (2006): Sources of heavy metals and polycyclic aromatic hydrocarbons in urban stormwater runoff. Science of the Total Environment 359, 145-155.

Burkhardt M (2006): Einsatz von biociden in Fassaden. Applica 12, 8-14.

Burkhardt M, Kupper T, Hean S, Haag R, Schmid P, Kohler M, Boller M (2007): Biocides used in building materials and their leaching behavior to sewer systems. Water Science and Technology 56, 63-67.

Burkhardt M, Zuleeg S, Vonbank R, Schmid P, Hean S, Lamani X, Bester K, Boller M (2011): Leaching of additives from construction materials to urban storm water runoff. Water Science and Technology 63, 1974-1982.

Burton GA, Pitt R (2002): Stormwater Effects Handbook: A Toolbox for Watershed Managers Lewis Publisher, 911 pp.

Cladière M, Gasperi J, Lorgeoux C, Bonhomme C, Rocher V, Tassin B (2013): Alkylphenolic compounds and bisphenol A contamination within a heavily urbanized area: case study of Paris. Environmental Science and Pollution Research 20, 2973-2983.

Clark SE, Burian S, Pitt R, Field R (2007): Urban wet-weather flows. Water Environment Research 79, 1166-1227.

Eriksson E, Baun A, Scholes L, Ledin A, Ahlman S, Revitt M, Noutsopoulos C, Mikkelsen PS (2007): Selected stormwater priority pollutants - a European perspective. Science of the Total Environment 383, 41-51.

European Chemicals Bureau 2002: Risk Assessment: 4-nonylphenol (branched) and nonylphenol, Rep. No. EUR 20387 EN. Office for Official Publications of the European Communities, Luxembourg

Fuchs S, Brombach H, Weiss G (2004): New database on urban runoff pollution, Novatech, Lyon, France, pp. 145-152. 
Gasperi J, Zgheib S, Cladière M, Rocher V, Moilleron R, Chebbo G (2012): Priority pollutants in urban stormwater: Part 2 - Case of combined sewers. Water Research 46, 6693-6703.

Gilbert S, Gasperi J, Rocher V, Lorgeoux C, Chebbo G (2012): Removal of alkylphenols and polybromodiphenylethers by a biofiltration treatment plant during dry and wetweather periods. Water Science and Technology 65, 1591-8.

Gromaire-Mertz MC, Garnaud S, Gonzalez A, Chebbo G (1999): Characterisation of urban runoff pollution in Paris. Water Science and Technology 39, 1-8.

Hites RA (2004): Polybrominated diphenyl ethers in the environment and in people: A metaanalysis of concentrations. Environmental Science \& Technology 38, 945-956.

Huang XJ, Pedersen T, Fischer M, White R, Young TM (2004): Herbicide runoff along highways. 1. Field observations. Environmental Science \& Technology 38, 32633271.

Kalmykova Y, Bjorklund K, Stromvall A-M, Blom L (2013): Partitioning of polycyclic aromatic hydrocarbons, alkylphenols, bisphenol A and phthalates in landfill leachates and stormwater. Water Research 47, 1317-28.

Kolpin DW, Thurman EM, Lee EA, Meyer MT, Furlong ET, Glassmeyer ST (2006): Urban contributions of glyphosate and its degradate AMPA to streams in the United States. Science of the Total Environment 354, 191-197.

Lamprea K, Ruban V (2011a): Characterization of atmospheric deposition and runoff water in a small suburban catchment. Environmental Technology 32, 1141-1149.

Lamprea K, Ruban V (2011b): Pollutant concentrations and fluxes in both stormwater and wastewater at the outlet of two urban watersheds in Nantes (France). Urban Water Journal 8, 219-231.

Metadier M, Bertrand-Krajewski JL (2012): The use of long-term on-line turbidity measurements for the calculation of urban stormwater pollutant concentrations, loads, pollutographs and intra-event fluxes. Water Research 46, 6836-6856.

Motelay-Massei A, Garban B, Phagne-Larcher K, Chevreuil M, Ollivon D (2006): Mass balance for polycyclic aromatic hydrocarbons in the urban watershed of Le Havre (France): Transport and fate of PAHs from the atmosphere to the outlet. Water Research 40, 1995-2006.

Muller K, Bach M, Hartmann H, Spiteller M, Frede HG (2002): Point- and nonpoint-source pesticide contamination in the Zwester Ohm catchment, Germany. J. Environ. Qual. 31, 309-318.

Muresan B, Lorgeoux C, Gasperi J, Moilleron R (2010): Fate and spatial variations of polybrominated diphenyl ethers in the deposition within a heavily urbanized area: Case of Paris (France). Water Science and Technology 62, 822-828.

Percot S 2012: Contributions of total atmopheric fallout to the pollutant loads at the catchment outlet of a samll urban catchment : case of Pin Sec in Nantes, Ecole centrale de Nantes, $210 \mathrm{pp}$.

Pitt R, Field R, Lalor M, Brown M (1995): Urban stormwater toxic pollutants - Assessement, sources and treatability. Water Environment Research 67, 260-275.

Pitt R, Maestre A (2005): Stormwater quality as described in the National Stormwater Quality Database (NSQD). 10th International Conference on Urban Drainage, Copenhagen/Denmark

Quaghebeur D, De Smet B, De Wulf E, Steurbaut W (2004): Pesticides in rainwater in Flanders, Belgium: results from the monitoring program 1997-2001. Journal of Environmental Monitoring 6, 182-190.

Rossi L 1998: Quality of urban stormwater. PhD Thesis Thesis, Ecole Polytechnique Fédérale de Lausanne, Suisse, 303 pp. 
Sabin LD, Lim JH, Stolzenbach KD, Schiff KC (2005): Contribution of trace metals from atmospheric deposition to stormwater runoff in a small impervious urban catchment. Water Research 39, 3929-3937.

Saget A 1994: Database on combined sewer overflow quality : pollutant distribution and design of interception bassin, $227 \mathrm{pp}$.

Schummer C, Tuduri L, Briand O, Appenzeller BM, Millet M (2012): Application of XAD-2 resin-based passive samplers and SPME-GC-MS/MS analysis for the monitoring of spatial and temporal variations of atmospheric pesticides in Luxembourg. Environmental Pollution 170, 88-94.

Smullen JT, Shallcross AL, Cave KA (1999): Updating the US nationwide urban runoff quality data base. Water Science and Technology 39, 9-16.

Soclo HH, Garrigues P, Ewald M (2000): Origin of polycyclic aromatic hydrocarbons (PAHs) in coastal marin sediments: case studies in Cotonou (benin) and Aquitaine (France) areas. Marine Pollution Bulletin 40, 387-396.

Staples CA, Dorn PB, Klecka GM, O'Block ST, Harris LR (1998): A review of the environmental fate, effects, and exposures of bisphenol A. Chemosphere 36, 21492173.

Sternbeck J, Sjodin A, Andreasson K (2002): Metal emissions from road traffic and the influence of resuspension-results from two tunnel studies. Atmospheric Environment $36,4735-4744$.

ter Schure AFH, Larsson P, Agrell C, Boon JP (2004): Atmospheric transport of polybrominated diphenyl ethers and polychlorinated biphenyls to the Baltic sea. Environmental Science \& Technology 38, 1282-1287.

Thorpe A, Harrison RM (2008): Sources and properties of non-exhaust particulate matter from road traffic: A review. Science of the Total Environment 400, 270-282.

Tlili K, Labadie P, Alliot F, Bourges C, Desportes A, Chevreuil M (2012): Polybrominated Diphenyl Ether Dynamics in Ambient Air and Atmospheric Bulk/Wet Deposition in Downtown Paris (France). Water Air and Soil Pollution 223, 1543-1553.

US-EPA 1989: A Probabilistic Methodology for Analyzing Water Quality Effects of Urban Runoff on Rivers and Streams, U.S. Environmental Protection Agency, Office of water, Washington D.C.128.

Ying GG, Williams B, Kookana R (2002): Environmental fate of alkylphenols and alkylphenol ethoxylates - a review. Environment International 28, 215-226.

Yunker MB, Macdonald RW, Goyette D, Paton DW, Fowler BR, Sullivan D, Boyd J (1999): Natural and anthropogenic inputs of hydrocarbons to the Strait of Georgia. Science of the Total Environment 225, 181-209.

Yunker MB, Macdonald RW, Vingarzan R, Mitchell RH, Goyette D, Sylvestre S (2002): PAHs in the Fraser River basin: a critical appraisal of PAH ratios as indicators of PAH source and composition. Organic Geochemistry 33, 489-515.

Zgheib S, Moilleron R, Chebbo G (2011a): Influence of the land use pattern on the concentrations and fluxes of priority pollutants in urban stormwater. Water Science and Technology 64, 1450-1458.

Zgheib S, Moilleron R, Saad M, Chebbo G (2011b): Partition of pollution between dissolved and particulate phases: What about emerging substances in urban stormwater catchments? Water Research 45, 913-925.

Zgheib S, Moilleron R, Chebbo G (2012): Priority pollutants in urban stormwater: Part 1Case of separate storm sewers. Water Research 46, 6683-6692. 


\section{Figure captions}

Figure 1: Locations of the three urban catchments considered for this study ......................... 27 Figure 2: Concentrations (mean $\pm \mathrm{SD}$, in $\mathrm{mg}^{-1} \mathrm{l}^{-1}$ ) of conventional water quality parameters for stormwater on the Sucy $(n=24)$, Pin Sec $(n=18)$ and Chassieu $(n=7)$ catchments ................... 28 Figure 3: PAH fingerprints (in \%, mean $\pm \mathrm{SD}$ ) in TAF and stormwater at the catchment outlet 
Figure 1: Locations of the three urban catchments considered for this study

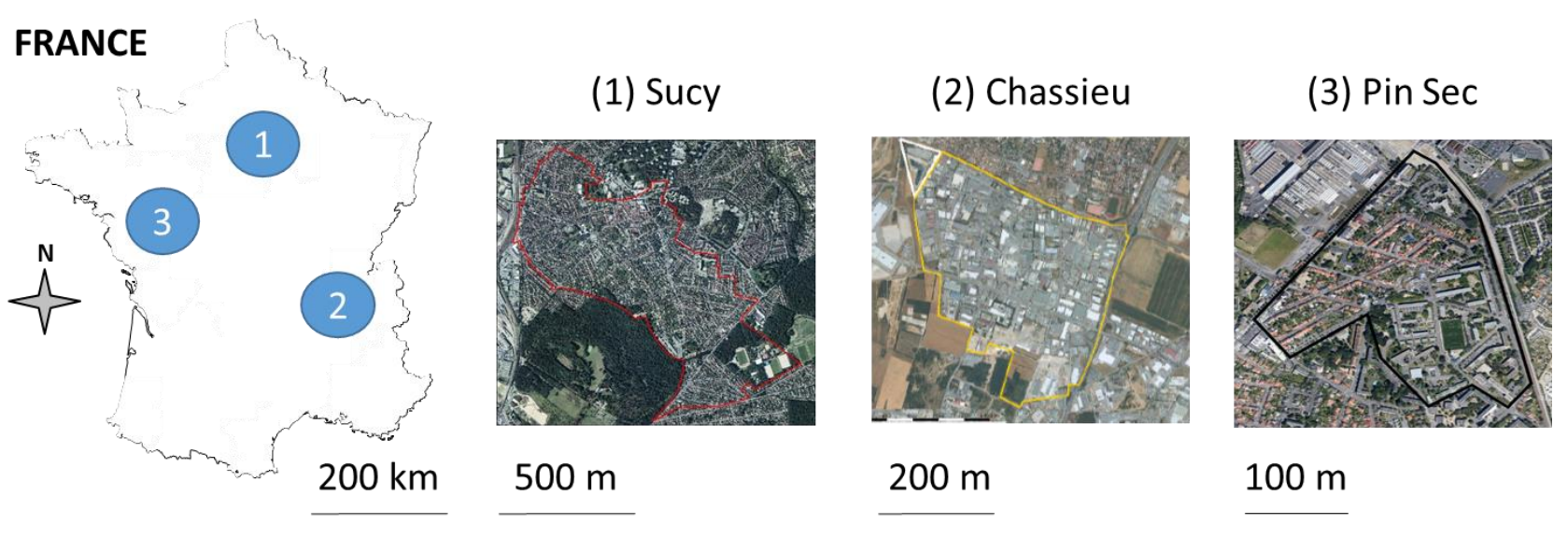




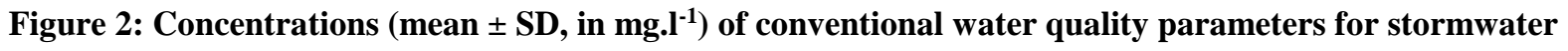
on the Sucy $(n=24)$, Pin Sec $(n=18)$ and Chassieu $(n=7)$ catchments

TSS

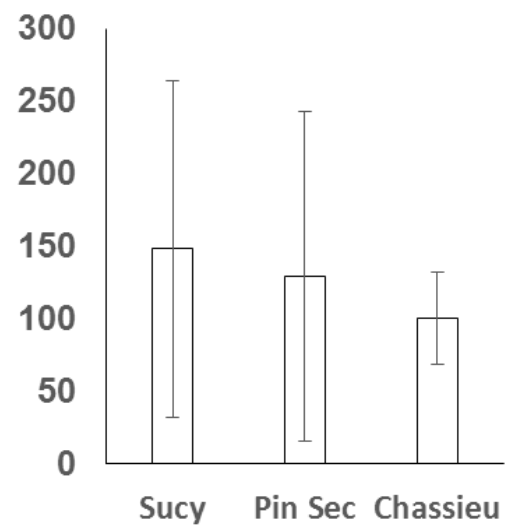

DOC

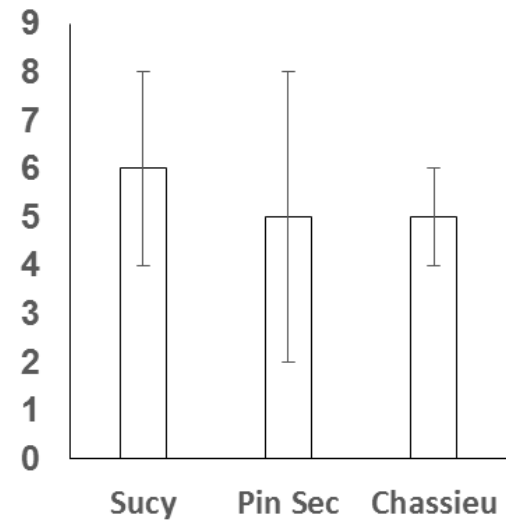

POC

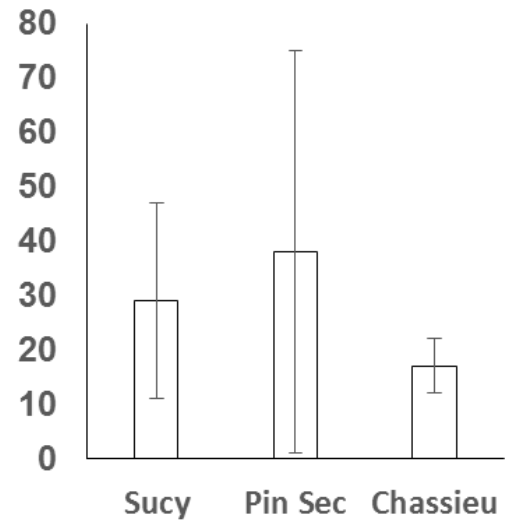


Figure 3: PAH fingerprints (in \%, mean \pm SD) in TAF and stormwater at the catchment outlet

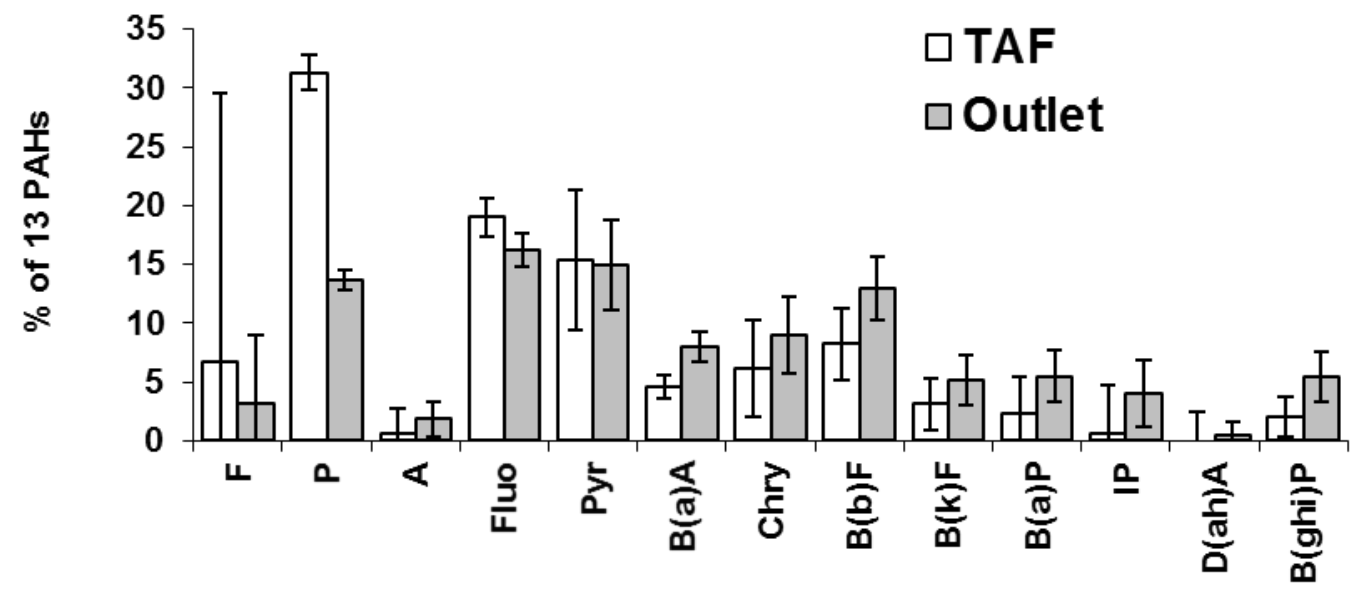




\section{Table captions}

Table 1: Urban catchment characteristics and description ................................................. 30

Table 2: Rain event characteristics on the three study sites (min-max and median values) .... 31

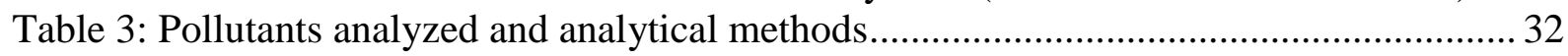

Table 4: Occurrence (in \%) of pollutants in TAF and stormwater....................................... 33

Table 5: Pollutant concentrations (mean \pm SD) in stormwater displaying site-to-site

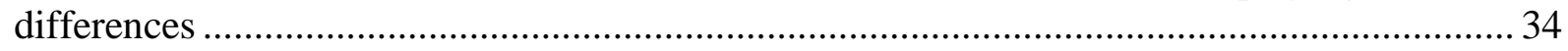

Table 6: Pollutant concentrations (mean $\pm \mathrm{SD}$, Q20 and Q80) in stormwater displaying no

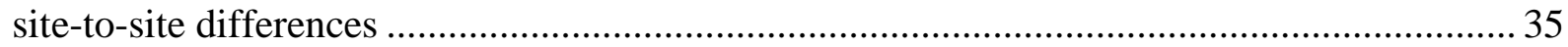

Table 7: Percentage of metals and organic pollutants in the particulate phase of stormwater

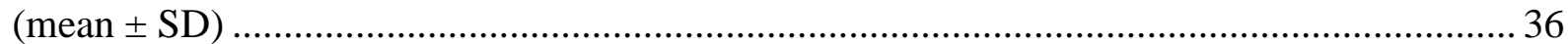

Table 8: Contributions (in \%) of TAF to stormwater pollution (mean \pm SD) ......................... 37 
Table 1: Urban catchment characteristics and description

\begin{tabular}{|c|c|c|c|c|c|c|}
\hline \multirow{2}{*}{ Site } & \multirow{2}{*}{ Location } & \multirow{2}{*}{$\begin{array}{c}\text { Area } \\
\text { (ha) }\end{array}$} & \multirow{2}{*}{$\begin{array}{c}\text { ISC }^{1} \\
(\%)\end{array}$} & \multirow{2}{*}{ Land use } & \multicolumn{2}{|c|}{ Rain events } \\
\hline & & & & & Total $^{2}$ & Compound $^{3}$ \\
\hline Sucy & Southeastern Paris & 228 & 21 & Residential & 24 & $7-10$ \\
\hline Pin Sec & Northeastern Nantes & 30 & 49 & $\begin{array}{l}\text { Single- and } \\
\text { multi-family } \\
\text { dwellings }\end{array}$ & 18 & $7-14$ \\
\hline Chassieu & Eastern Lyon & 185 & 75 & Industrial & 7 & $2-5$ \\
\hline
\end{tabular}

1) ISC = impervious surface coefficient (\%); 2) Number of rain events collected on the site; 3) Number of rain events for a group of compounds. 
Table 2: Rain event characteristics on the three study sites (min-max and median values)

\begin{tabular}{|c|c|c|c|c|c|}
\hline & $\mathrm{H}^{1}(\mathrm{~mm})$ & Duration $(\mathrm{hh}: \mathrm{mm})$ & $\mathrm{I}_{\text {mean }}\left(\mathrm{mm}^{-1} \mathrm{~h}^{-1}\right)$ & $\mathrm{I}_{\max }{ }^{2}\left(\mathrm{~mm}^{-1}\right)$ & $\mathrm{PDWP}^{3}(\mathrm{~d})$ \\
\hline Sucy & $1.2-38.6$ & $00: 35-26: 20$ & $0.43-3.77$ & $2.4-24$ & $0.17-9.18$ \\
\hline$(\mathrm{n}=24)$ & 8.43 & $06: 52$ & 1.48 & 7.92 & 2.1 \\
\hline Pin Sec & $2.3-49.9$ & $02: 40-60: 35$ & Not estimated & $2.4-28.8$ & $0.19-22.29$ \\
\hline$(\mathrm{n}=18)$ & 15.4 & $19: 14$ & - & 11.4 & 2.60 \\
\hline Chassieu & $2.4-50.0$ & $03: 07-31: 38$ & $0.8-1.7$ & $4.7-22.7$ & $0.2-9.8$ \\
\hline$(\mathrm{n}=7)$ & 18.8 & $14: 31$ & 1.2 & 12.2 & 2.8 \\
\hline
\end{tabular}

1) Depth of precipitation; 2) Imax evaluated over 5-min intervals; 3) Preceding dry weather period, in days. Min-Max values, as well as median values. 
Table 3: Pollutants analyzed and analytical methods

\begin{tabular}{|c|c|c|}
\hline Groups (n=77) & Methods $^{1}$ & Substances and abbreviations \\
\hline $\begin{array}{l}\text { Metals } \\
(n=14)\end{array}$ & $\begin{array}{l}\text { ICP-MS } \\
\text { ICP-AES }\end{array}$ & $\begin{array}{l}\text { Arsenic (As), Cadmium }(\mathrm{Cd}) \text {, Chromium }(\mathrm{Cr}) \text {, Copper }(\mathrm{Cu}) \text {, Nickel } \\
(\mathrm{Ni}) \text {, Lead }(\mathrm{Pb}) \text {, Zinc }(\mathrm{Zn}) \text {, Platinum }(\mathrm{Pt}) \text {, Vanadium }(\mathrm{V}) \text {, Cobalt } \\
(\mathrm{Co}) \text {, Molybdenum }(\mathrm{Mo}) \text {, Strontium }(\mathrm{Sr}) \text {, Barium }(\mathrm{Ba}) \text {, Titan }(\mathrm{Ti})\end{array}$ \\
\hline $\begin{array}{l}\text { PAHs } \\
(\mathrm{n}=16)\end{array}$ & GC-Tof & 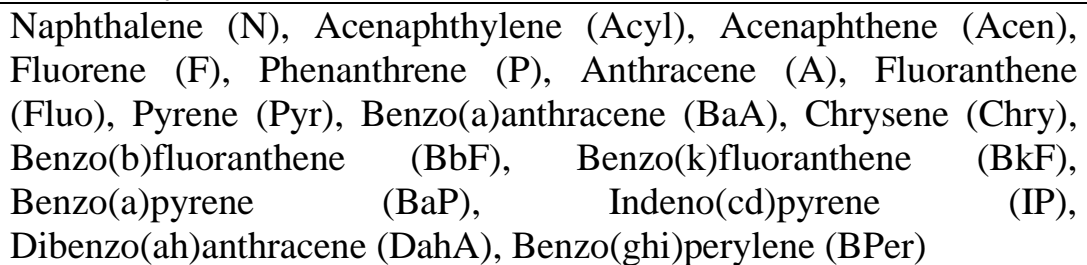 \\
\hline $\begin{array}{l}\text { Pesticides } \\
\quad(\mathrm{n}=30)\end{array}$ & $\begin{array}{l}\text { GC-MS } \\
\text { LC-MSMS } \\
\text { LC-Fluo }\end{array}$ & $\begin{array}{l}\text { Metaldehyde, Glyphosate, amino methyl phosphonic acid (AMPA), } \\
\text { Glufosinate, Chlorfenviphos, Diuron, Endosulfan A, Folpel, } \\
\text { Isoproturon, Aldrin, Dieldrin, Isodrin, Mecoprop, 2,4- } \\
\text { Dichlorophenoxyacetic acid (2,4-D), 4-chloro-2-méthyl phenoxy } \\
\text { acetic acid (2,4-MCPA), Trichlopyr, Carbendazim, Tsothiazolinone, } \\
\text { Irgarol 1051, Terbutryn, Acetochlor, Metolachlor, Pendimethalin, } \\
\text { Epoxiconazole, Tebuconazole, Fenpropidine, Chlorothalonil, } \\
\text { Metazachlor, Diflufenicanil, Deltamethrine }\end{array}$ \\
\hline $\begin{array}{c}\text { PBDEs } \\
(\mathrm{n}=9)\end{array}$ & GC-MS & $\begin{array}{l}\text { BDE-28 [tri], BDE-47 [tetra], BDE-99 [penta], BDE-100 [penta], } \\
\text { BDE-153 [hexa], BDE-154 [hexa], BDE-183 [hepta], BDE-205 } \\
\text { [octa], BDE-209 [deca] }\end{array}$ \\
\hline $\begin{array}{l}\text { Bisphenol A and } \\
\text { APnEOs } \\
(\mathrm{n}=1+7)\end{array}$ & LC-MSMS & $\begin{array}{l}\text { Bisphenol A (BPA) } \\
\text { Nonylphenol (NP), Nonylphenol monoethoxylate (NP1EO), } \\
\text { Nonylphenol diethoxylate (NP2EO), Nonylphenol monocarboxylate } \\
\text { (NP1EC), 4-tert-octylphenol (OP), Octylphenol monoethoxylate } \\
\text { (OP1EO), octylphenol diethoxylate (OP2EO) }\end{array}$ \\
\hline
\end{tabular}

1) Analytical methods: ICP-MS = inductively coupled plasma with a mass spectrometer, ICP-AES = inductively coupled plasma with atomic emission spectroscopy, GC-MS = gas chromatography with a mass spectrometer, GC-Tof $=$ gas chromatography with a time-of-flight mass spectrometer, LC-fluo = liquid chromatography with a fluorescent detector, LC$M S M S$ = liquid chromatography with a tandem mass spectrometer . 
Table 4: Occurrence (in \%) of pollutants in TAF and stormwater

\begin{tabular}{|c|c|c|c|c|c|c|}
\hline & \multicolumn{2}{|c|}{ Sucy } & \multicolumn{2}{|c|}{ Pin Sec } & \multicolumn{2}{|c|}{ Chassieu } \\
\hline Substances & TAF & Outlet & TAF & Outlet & TAF & Outlet \\
\hline Metals & 8 events & 8 events & 15 events & 15 events & 5 events & 5 events \\
\hline$>80 \%$ & \multicolumn{6}{|c|}{$\mathrm{As}, \mathrm{Cd}, \mathrm{Cu}, \mathrm{Ni}, \mathrm{Pb}, \mathrm{Sr}, \mathrm{Ti}, \mathrm{V}, \mathrm{Zn}$} \\
\hline $\mathrm{Co}$ & $57 \%$ & $57 \%$ & $0 \%$ & $86 \%$ & $40 \%$ & $100 \%$ \\
\hline Mo & $25 \%$ & $25 \%$ & $31 \%$ & $31 \%$ & $20 \%$ & $80 \%$ \\
\hline $\mathrm{Pt}$ & $63 \%$ & $63 \%$ & $54 \%$ & $50 \%$ & $20 \%$ & $80 \%$ \\
\hline PAHs & 8 events & 8 events & 7 events & 7 events & 4 events & 4 events \\
\hline$>80 \%$ & \multicolumn{6}{|c|}{ N, Acen, F, P, Fluo, Pyr } \\
\hline Acyl & $75 \%$ & $75 \%$ & $50 \%$ & $71 \%$ & $75 \%$ & $75 \%$ \\
\hline A & $25 \%$ & $75 \%$ & $25 \%$ & $43 \%$ & $25 \%$ & $100 \%$ \\
\hline $\mathrm{B}(\mathrm{a}) \mathrm{A}$ & $63 \%$ & $88 \%$ & $25 \%$ & $100 \%$ & $75 \%$ & $100 \%$ \\
\hline Chry & $88 \%$ & $100 \%$ & $50 \%$ & $100 \%$ & $75 \%$ & $100 \%$ \\
\hline $\mathrm{B}(\mathrm{b}) \mathrm{F}$ & $75 \%$ & $100 \%$ & $50 \%$ & $100 \%$ & $100 \%$ & $100 \%$ \\
\hline $\mathrm{B}(\mathrm{k}) \mathrm{F}$ & $71 \%$ & $100 \%$ & $25 \%$ & $100 \%$ & $50 \%$ & $100 \%$ \\
\hline $\mathrm{B}(\mathrm{a}) \mathrm{P}$ & $50 \%$ & $75 \%$ & $0 \%$ & $100 \%$ & $50 \%$ & $75 \%$ \\
\hline IP & $25 \%$ & $75 \%$ & $0 \%$ & $86 \%$ & $0 \%$ & $75 \%$ \\
\hline $\mathrm{D}$ (ah)A & $0 \%$ & $63 \%$ & $0 \%$ & $14 \%$ & $0 \%$ & $0 \%$ \\
\hline B(ghi)P & $50 \%$ & $75 \%$ & $25 \%$ & $100 \%$ & $25 \%$ & $100 \%$ \\
\hline Pesticides & 7 events & 7 events & 8 events & 8 events & 4 events & 4 events \\
\hline$<20 \%$ & \multicolumn{6}{|c|}{$\begin{array}{c}\text { metaldehyde, chlorfenviphos, endosulfan A, folpel, aldrin, dieldrin, isodrin, 2,4-D, trichlopyr, } \\
\text { isothiazolinone, irgarol 1051, terbutryn, acetochlor, s-metolachlor, pendimethalin, epoxiconazole } \\
\text { Tebuconazole, fenpropidine, chlorothalonil, metazachlor, deltamethrine }\end{array}$} \\
\hline isoproturon & $100 \%$ & $100 \%$ & $33 \%$ & $29 \%$ & $75 \%$ & $100 \%$ \\
\hline Diuron & $67 \%$ & $100 \%$ & $67 \%$ & $71 \%$ & $75 \%$ & $100 \%$ \\
\hline carbendazim & $67 \%$ & $100 \%$ & $0 \%$ & $71 \%$ & $75 \%$ & $100 \%$ \\
\hline 2,4-MCPA & $50 \%$ & $33 \%$ & $67 \%$ & $29 \%$ & $75 \%$ & $75 \%$ \\
\hline mecoprop & $50 \%$ & $50 \%$ & $17 \%$ & $0 \%$ & $75 \%$ & $25 \%$ \\
\hline glyphosate & $50 \%$ & $40 \%$ & $67 \%$ & $70 \%$ & $75 \%$ & $75 \%$ \\
\hline AMPA & $50 \%$ & $40 \%$ & $44 \%$ & $50 \%$ & $75 \%$ & $75 \%$ \\
\hline glufosinate & $50 \%$ & $40 \%$ & $67 \%$ & $70 \%$ & $50 \%$ & $75 \%$ \\
\hline diflufenicanil & $17 \%$ & $40 \%$ & $0 \%$ & $29 \%$ & $0 \%$ & $0 \%$ \\
\hline PBDEs & 12 events & 12 events & 7 events & 7 events & 2 events & 2 events \\
\hline$>80 \%$ & \multicolumn{6}{|c|}{ BDE-47, BDE-209 } \\
\hline BDE-28 & $88 \%$ & $100 \%$ & $80 \%$ & $75 \%$ & $100 \%$ & $100 \%$ \\
\hline BDE-99 & $100 \%$ & $100 \%$ & $80 \%$ & $50 \%$ & $100 \%$ & $50 \%$ \\
\hline BDE-100 & $100 \%$ & $100 \%$ & $80 \%$ & $75 \%$ & $100 \%$ & $100 \%$ \\
\hline BDE-153 & $63 \%$ & $75 \%$ & $40 \%$ & $50 \%$ & $50 \%$ & $50 \%$ \\
\hline BDE-154 & $38 \%$ & $38 \%$ & $0 \%$ & $25 \%$ & $0 \%$ & $0 \%$ \\
\hline BDE-183 & $50 \%$ & $50 \%$ & $0 \%$ & $50 \%$ & $0 \%$ & $100 \%$ \\
\hline BPA/APnEO & 12 events & 12 events & 7 events & 7 events & 2 events & 2 events \\
\hline$>80 \%$ & \multicolumn{6}{|c|}{ BPA, OP, OP2EO, NP, NP1EO, NP2EO, NP1EC } \\
\hline OP1EO & $50 \%$ & $63 \%$ & $75 \%$ & $50 \%$ & $50 \%$ & $100 \%$ \\
\hline$<20 \%$ & & $20-50 \%$ & & $50-80 \%$ & & $>80 \%$ \\
\hline
\end{tabular}


Table 5: Pollutant concentrations (mean \pm SD) in stormwater displaying site-to-site differences

\begin{tabular}{|c|c|c|c|c|c|c|c|c|}
\hline & & \multicolumn{2}{|c|}{ Sucy } & \multicolumn{2}{|c|}{ Pin Sec } & \multicolumn{2}{|c|}{ Chassieu } & \\
\hline & Substances & Mean & $\mathrm{SD}$ & Mean & SD & Mean & $\mathrm{SD}$ & References \\
\hline Metals* & Events & \multicolumn{2}{|c|}{8} & \multicolumn{2}{|c|}{15} & \multicolumn{2}{|c|}{5} & \\
\hline & As & 1.18 & 0.80 & 4.04 & 2.70 & 0.88 & 0.66 & - \\
\hline & $\mathrm{Cr}$ & 3.55 & 2.54 & 1.95 & 1.46 & 6.20 & 5.00 & $\begin{array}{c}2.1-14^{1} \\
3.0-195^{2} \\
2.1-20^{3}\end{array}$ \\
\hline & $\mathrm{Cu}$ & 38.00 & 28.41 & 14.87 & 11.33 & 34.62 & 29.19 & $\begin{array}{c}41.0-197^{2} \\
5.9-37^{3} \\
66.6-54.8^{4}\end{array}$ \\
\hline & $\mathrm{Ni}$ & 2.88 & 1.97 & 3.14 & 2.28 & 6.64 & 4.53 & $\begin{array}{l}2.1-8.5^{3} \\
2.2-32^{1}\end{array}$ \\
\hline & $\mathrm{Sr}$ & 112.83 & 79.62 & 28.98 & 29.46 & 51.40 & 34.17 & - \\
\hline & $\mathrm{Zn}$ & 212.35 & 145.08 & 126.34 & 87.06 & 239.78 & 196.77 & $\begin{array}{c}64-536^{1} \\
52-502^{2} \\
32-320^{3} \\
176-140^{4}\end{array}$ \\
\hline PAHs** & Events & \multicolumn{2}{|c|}{8} & \multicolumn{2}{|c|}{7} & \multicolumn{2}{|c|}{4} & \\
\hline & Fluo & 217 & 193 & 105 & 72 & 97 & 65 & $169^{5}$ \\
\hline & Pyr & 176 & 156 & 104 & 72 & 88 & 59 & $170^{5}$ \\
\hline & $\sum_{13}$ PAHs & 1237 & 1127 & 723 & 491 & 644 & 406 & \\
\hline & $\sum_{16} \mathrm{PAHs}$ & 1362 & 1227 & 892 & 604 & 1135 & 770 & $3300^{5}$ \\
\hline PBDEs** & Events & \multicolumn{2}{|c|}{12} & \multicolumn{2}{|c|}{7} & \multicolumn{2}{|c|}{2} & \\
\hline & BDE-209 & 25 & 23 & 90 & 111 & \multicolumn{2}{|c|}{$86-98 * * *$} & \\
\hline & $\sum_{9}$ PBDEs & 23 & 23 & 91 & 113 & \multicolumn{2}{|c|}{$232-98 * * *$} & \\
\hline
\end{tabular}

1) Lamprea et al. (2011a), 2) Rossi (1998), 3) Sabin et al. (2005) 4) NURP database, mean and median values, 5) Zgheib et al. (2011), median values, *) Metal concentrations in $\mu g . l^{-1}$, **) Concentrations in ng. $l^{-1}$ for organic pollutants, ***) Only two events collected. 
Table 6: Pollutant concentrations (mean \pm SD, Q20 and Q80) in stormwater displaying no site-to-site differences

\begin{tabular}{|c|c|c|c|c|c|c|}
\hline & & Mean & SD & Q20 & Q80 & Reference \\
\hline Metals* & $\mathrm{Cd}$ & 0.32 & 0.31 & 0.11 & 0.39 & $0.5-2.2^{1}$ \\
\hline \multirow[t]{5}{*}{$(n=28)$} & $\mathrm{Co}$ & 3.45 & 3.13 & 1.00 & 3.68 & - \\
\hline & Mo & 7.68 & 13.09 & 1.10 & 12.05 & - \\
\hline & $\mathrm{Pb}$ & 21.52 & 20.73 & 6.79 & 33.22 & $175-131^{2}$ \\
\hline & $\mathrm{Ti}$ & 27.80 & 28.60 & 9.70 & 37.50 & \\
\hline & $\mathrm{V}$ & 4.86 & 2.84 & 2.55 & 6.79 & \\
\hline Pesticides $* *, * * *$ & Glyphosate & 337 & 806 & 95 & 198 & \\
\hline \multirow[t]{6}{*}{$(n=19)$} & Glufosinate & 756 & 10121 & 6 & 389 & \\
\hline & AMPA & 824 & 7077 & 16 & 469 & \\
\hline & Diuron & 1213 & 10784 & 25 & 795 & \\
\hline & Isoproturon & 88 & 929 & 3 & 53 & \\
\hline & Carbendazim & 213 & 1355 & 7 & 195 & \\
\hline & Mecoprop & 3 & 7 & 1 & 2 & \\
\hline $\begin{array}{c}\text { APnEO and } \\
\text { BPA } * * *^{*}\end{array}$ & BPA & 552 & 510 & 207 & 817 & $<$ LOD- $107,000^{3}$ \\
\hline \multirow[t]{7}{*}{$(\mathrm{n}=21)$} & $\mathrm{OP}$ & 61 & 37 & 35 & 72 & \\
\hline & OP1EO & 23 & 25 & 9 & 22 & \\
\hline & OP2EO & 10 & 11 & 4 & 14 & \\
\hline & NP & 359 & 228 & 187 & 509 & $\begin{array}{c}<\mathrm{LOQ}-7,300^{3} \\
160-920^{4}\end{array}$ \\
\hline & NP1EO & 347 & 543 & 69 & 428 & \\
\hline & NP2EO & 164 & 216 & 52 & 141 & \\
\hline & NP1EC & 466 & 1179 & 160 & 324 & \\
\hline
\end{tabular}

1) Rossi (1998), 2) NURP database, mean and median values, 3) Kalmykova et al. (2013), 4) Bressy et al. (2012), d10-d90 values, *) Metal concentrations in $\mu g . l^{-1}$, **) For pesticides, the site-to-site differences were not tested, ***) Concentrations in $n g . l^{-1}$ for organic pollutants. 
Table 7: Percentage of metals and organic pollutants in the particulate phase of stormwater (mean \pm SD)

\begin{tabular}{|c|c|c|c|c|}
\hline & $<20 \%$ & $<50 \%$ & $50-80$ & $>80 \%$ \\
\hline Metals & $\operatorname{Sr}(13 \pm 10)$ & As $(48 \pm 18)$ & $\begin{array}{c}\mathrm{Cd}(63 \pm 30) \\
\mathrm{Mo}(63 \pm 40) \\
\mathrm{Ni}(54 \pm 18) \\
\mathrm{V}(62 \pm 18) \\
\mathrm{Zn}(60 \pm 23) \\
\mathrm{Cu}(73 \pm 13)\end{array}$ & $\begin{array}{l}\mathrm{Co}(80 \pm 34) \\
\mathrm{Cr}(85 \pm 11) \\
\mathrm{Pb}(94 \pm 4) \\
\mathrm{Ti}(94 \pm 9)\end{array}$ \\
\hline PAHs & & $\mathrm{N}(44 \pm 28)$ & $\begin{array}{l}\text { A }(60 \pm 44) \\
F(70 \pm 31)\end{array}$ & $\begin{array}{c}\text { Acyl }(90 \pm 37) \\
\text { Acen }(82 \pm 28) \\
\text { P }(84 \pm 12) \\
\text { Fluo }(93 \pm 5) \\
\text { Pyr }(93 \pm 5) \\
\text { B(a)A }(100 \pm 22) \\
\text { Chry }(97 \pm 4) \\
\text { B(b)F }(99 \pm 2) \\
\text { B(k)F }(99 \pm 2) \\
\text { B(a)P }(100 \pm 1) \\
\text { IP, d(ah)A }\left(100^{*}\right) \\
\text { B(ghi)P }(99 \pm 1)\end{array}$ \\
\hline Pesticides & $\begin{array}{c}\text { Diuron }(6 \pm 41) \\
\text { Glyphosate }(14 \pm 43)\end{array}$ & $\begin{array}{l}\text { Glyfosinate }(43 \pm 46) \\
\text { Isoproturon }(42 \pm 43)\end{array}$ & & \\
\hline PBDEs & & & $\begin{array}{l}\text { BDE-28 }(71 \pm 33), \\
\text { BDE-100 }(55 \pm 34)\end{array}$ & $\begin{array}{l}\text { BDE-47 }(95 \pm 33) \\
\text { BDE-99 }(86 \pm 42) \\
\text { BDE-209 }(99 \pm 7)\end{array}$ \\
\hline $\begin{array}{l}\text { APnEO } \\
\text { and BPA }\end{array}$ & $\begin{array}{c}\text { BPA }(18 \pm 11) \\
\text { OP1EO }(14 \pm 23)\end{array}$ & $\begin{array}{c}\text { OP }(45 \pm 22) \\
\text { OP2EO }(32 \pm 16) \\
\text { NP }(40 \pm 22) \\
\text { NP1EO }(39 \pm 20) \\
\text { NP2EO }(29 \pm 17) \\
\text { NP1EC }(38 \pm 30) \\
\end{array}$ & & \\
\hline
\end{tabular}

*) Detected only in the particulate phase. 
Table 8: Contributions (in \%) of TAF to stormwater pollution (mean \pm SD)

\begin{tabular}{|c|c|c|c|}
\hline & $* \mathrm{C}_{[\mathrm{TAF}]} / \mathrm{C}_{[\text {Outlet }]}<10 \%$ & $\mathrm{C}_{[\mathrm{TAF}]} / \mathrm{C}_{[\text {Outlet }]}<20 \%$ & $\mathrm{C}_{[\mathrm{TAF}]} / \mathrm{C}_{[\text {Outlet }]}>20 \%$ \\
\hline Water parameters & $\begin{array}{l}\text { TSS }(8 \pm 11) \\
\text { POC }(9 \pm 13)\end{array}$ & & DOC $(25 \pm 15)$ \\
\hline \multirow[b]{2}{*}{ Metals } & $\begin{array}{l}\text { As }(7 \pm 4) \\
\operatorname{Sr}(9 \pm 7)\end{array}$ & $\begin{array}{l}\mathrm{Ti}(13 \pm 24) \\
\mathrm{Pb}(11 \pm 12) \\
\mathrm{Cu}(20 \pm 17)\end{array}$ & $\begin{array}{l}\mathrm{Cu}(20 \pm 17) \\
\mathrm{Cr}(32 \pm 53) \\
\mathrm{Ni}(32 \pm 31) \\
\mathrm{Cd}(33 \pm 29)\end{array}$ \\
\hline & $\begin{array}{c}\mathrm{Sr}_{\text {Sucy }}(3 \pm 1) \\
\mathrm{Sr}_{\text {Chassieu }}(5 \pm 3) \\
\mathrm{Zn} \text { Sucy }(9 \pm 5) \\
\mathrm{Cr}_{\text {Sucy }}(10 \pm 5) \\
\mathrm{Cr}_{\text {Chassieu }}(8 \pm 6)\end{array}$ & $\begin{array}{c}\text { Sr Pin Sec }(14 \pm 6) \\
\mathrm{Zn} \text { Chassieu }(15 \pm 9)\end{array}$ & $\begin{array}{c}\text { Zn Pin Sec }(86 \pm 127) \\
\text { Cr Pin Sec }^{2}(55 \pm 68)\end{array}$ \\
\hline PAHs & $\begin{array}{l}\mathrm{B}(\mathrm{a}) \mathrm{P}(4 \pm 11) \\
\mathrm{I}(\mathrm{cd}) \mathrm{P}(1 \pm 4), \\
\mathrm{B}(\mathrm{ghi}) \mathrm{P}(4 \pm 8)\end{array}$ & $\begin{array}{c}\text { A }(13 \pm 34) \\
\text { Fluo }(17 \pm 19) \\
\text { Pyr }(14 \pm 14) \\
\text { Chry }(13 \pm 20) \\
\text { B(b)F }(14 \pm 21) \\
\text { B(k)F }(11 \pm 20) \\
\text { B(a)A }(11 \pm 15)\end{array}$ & $\begin{array}{c}\mathrm{N}(68 \pm 32) \\
\text { Acyl }(24 \pm 25) \\
\text { Acen }(40 \pm 45) \\
\mathrm{F}(28 \pm 20) \\
\mathrm{P}(26 \pm 22)\end{array}$ \\
\hline PBDEs & $\begin{array}{l}\text { BDE-47 }(6 \pm 4) \\
\text { BDE-99 }(9 \pm 15) \\
\text { BDE-154 }(5 \pm 6)\end{array}$ & $\begin{array}{c}\text { BDE } 28(18 \pm 24) \\
\text { BDE-100 }(16 \pm 14) \\
\text { BDE-153 }(12 \pm 16) \\
\text { BDE-209 }(11 \pm 19)\end{array}$ & \\
\hline APnEO and BPA & $\begin{array}{c}\text { BPA }(4 \pm 3) \\
\text { NP1EC }(4 \pm 10) \\
\text { OP }(8 \pm 5) \\
\text { BPA }(4 \pm 4)\end{array}$ & $\begin{array}{c}\text { NP }(19 \pm 16) \\
\text { NP1EO }(18 \pm 21) \\
\text { OP1EO }(16 \pm 21) \\
\text { OP2EO }(17 \pm 13)\end{array}$ & NP2EO $(32 \pm 21)$ \\
\hline
\end{tabular}

$* C_{[T A F]} / C_{[O u t e t]}:$ concentrations found for total atmospheric fallout / concentrations measured in stormwater at the catchment outlet. 